\title{
НОРМАТИВНО-ПРАВОВІ ТА ОРГАНІЗАЦІЙНО-ПРАВОВІ ПИТАННЯ ПРОВЕДЕННЯ ОГЛЯДУ МІСЦЯ ПОДІЇ НА ТЕРИТОРІЇ ПРОВЕДЕННЯ ОПЕРАЦІЇ ОБ'ЄДНАНИХ СИЛ
}

Тетерятник Г. $K$.

Стаття присвячена особливостям нормативного регулювання й організаційно-правових питань огляду місця події на території проведення Операції Об'єднаних сил (далі - ООС). Виділено фактори, які впливають на специфіку проведення слідчих (розшукових) дій. Досліджено питання розширення повноважень оперативних підрозділів у зоні ООС, а саме надання їм права проводити огляд місия подіі до внесення відомостей до єдиного реєстру досудових розслідувань (далі - ЄРДР) і без доручення слідчого, прокурора у невідкладних випадках. Акцентовано увагу на необхідності приведення у відповідність нормативно-правових актів, які регулюють питання залучення судового медика до проведення огляду трупа, а також визначення можливості проведення огляду трупа як окремої процесуальної дії до внесення відомостей до ЄРДР. Проаналізовано передумови й перспективи впровадження процедури 3D-сканування під час огляду місця подіi.

Запропоновані зміни до чинного Кримінального процесуального кодексу України (далі - КПК) з метою підвищення оперативності, ефективності огляду місця подіі, закріплення гарантій безпеки учасників процесуальної дії на території проведення ООС.

Ключові слова: слідчі (розшукові) діі, огляд місця подіi, ООС, огляд труna, 3D-сканування.

Статья посвящена особенностям нормативного регулирования и организационно-правовым вопросам осмотра места происшествия на территории проведения Операции Объединенных сил (далее - ООС). Выделены факторы, влияющие на специфику проведения следственных (розыскных) действий. Исследован вопрос расширения полномочий сотрудников оперативных подразделений в зоне ООС, а именно предоставления им права проводить осмотр места происшествия до внесения сведений в ЕРДР и без поручения следователя, прокурора в неотложных случаях. Акцентировано внимание на необходимости приведения в соответствие нормативно-правовых актов, регулирующих вопросы привлечения судебного медика к проведению осмотра трупа, а также определения возможности прове дения осмотра трупа как отдельного процессуального действия до внесения сведений в Единый реестр досудебных расследований (далее - ЕРДР). Проанализированы предпосылки и перспективы внедрения процедуры 3D-сканирования при осмотре места происшествия.

Предложены изменения в действующий Уголовно-процессуальный кодекс Украины (далее - УПК) с целью повышения оперативности, эффективности осмотра места происшествия, установления гарантий безопасности участников процессуального действия на территории проведения ООС.

Ключевые слова: следственные (розыскные) действия, осмотр места происшествия, ООС, осмотр трупа, 3D-сканирование.

Тетерятник Г. К., 2019
The article is devoted to peculiarities of regulatory and legal issues of crime scene examination in the territory of Operation of United forces (OUF). The factors influencing the specifics of inspection of the scene on the territory of the OUF. The external factors that play a role in shaping and organization of this type of inspection include: the threat of repeated attacks, the dual bombings, activity sabotage-prospecting group, the mining areas and others. These factors lead to the need for expeditious conduct of inspection of the scene, creating additional security guarantees for the members of the investigative team and other participants in investigative actions.

We study the problem of empowerment of employees of operational units in the one of negative feedback is giving them the right to inspect the scene before making the information in Unified register of state investigations (URSI) and without instructions of the investigator, the Prosecutor, in urgent cases.

Attention is accented on the necessity of harmonization of normative-legal acts regulating the issues of raising the medical officer for examination of the corpse. The possibility of such inspection with the participation of the medical officer outside the scene, in case of danger. In addition, the possibility of inspection of the corpse as separate proceedings to the entry of information in URSI.

The existence of multiple risk factors when conducting inspection on the territory of the EP explores the possibilities of applying modern forensic methods and equipment for the effective and efficient conduct of the investigative procedure. The article analyzes the preconditions and prospects of implementation of procedure 3-D scan while inspecting the scene.

The proposed changes in the existing criminal procedure code of Ukraine with the purpose of increase of efficiency of examination of the scene, to establish safeguards to ensure the safety of participants in the procedural actions in the territory of the OUF.

Key words: investigative (search) actions, the inspection of the scene, OUF, inspection of the corpse, a 3-D scan.

Постановка проблеми та їі актуальність. Проведення слідчих (розшукових) дій $€$ основним засобом доказування. Не становить виключення й розслідування кримінальних правопорушень, учинених на тимчасово окупованих територіях. Відповідно до Закону України «Про забезпечення прав і свобод громадян та правовий режим на тимчасово окупованій території України» від 15 квітня 2014 р. № 1207-VII [1] й роз'яснювального листа Генеральної прокуратури України від 2 жовтня 2014 р. № 14/2/2-67-14741 на тимчасово окупованих територіях неможливо проводити слідчі (розшукові) дії й оперативно-розшукові заходи. Однак на території проведення Операції Об'єднаних сил проведення процесуальних дій в окремих зонах $є$ можливим. Водночас необхідним залишається створення балансу між специфічністю окремих процедур кримінального провадження й повноцінною реалізацією завдань кримінального провадження, передбачених ст. 2 КПК України. 
(Слід зауважити: в контексті дослідження, визначаючи специфіку проведення огляду в районі здійснення ООС, маємо на увазі випадки, коли слідча (розшукова) дія відбувається в умовах, що створюють або можуть створити небезпеку для життя та/чи здоров'я іï учасників).

Однією з важливих слідчих (розшукових) дій, якій відводиться вагома роль у процесі доказування, $є$ огляд місця події. Відповідно до ч. 1 ст. 237 КПК України огляд проводиться з метою виявлення та фіксації відомостей щодо обставин кримінального правопорушення. Невідкладність проведення огляду місця події пов'язана з необхідністю максимального збереження слідів кримінального правопорушення. Тоді як під час здійснення огляду місця події за окремими категоріями злочинів (пов'язаними з учиненням терористичних актів, масовою загибеллю людей тощо) необхідною умовою ефективності його проведення $є$ якісна підготовка (наявність відповідних криміналістичних засобів, спеціалістів, які залучаються до процесуальної дії). Водночас обов'язковим під час усіх слідчих (розшукових) дій $є$ забезпечення прав і законних інтересів осіб, які беруть у них участь.

Аналіз останніх досліджень і публікацій. На монографічному рівні питання, пов'язані з досудовим розслідуванням, у тому числі проведенням слідчих (розшукових) дій, у надзвичайних правових режимах досліджувались у роботах В.М. Григор'єва, О.В. Лазукової, О.В. Сачко, А.Б. Сергеєва та інших.

Окремим аспектам доказування й проведення слідчих (розшукових) дій у районі ООС присвячені публікації Д.М. Бусова, С.С. Кудінова, М.О. Лисенкова, В.А. Маякова М.С. Цуцкірідзе, М.О. Яковенка та інших.

Використанню сучасних засобів, які можуть підвищити ефективність огляду в умовах ООС, присвячені роботи С.С. Данець, О.М. Дуфенюк, А.І. Непоради, О.В. Сараєва, Р.М. Шехавцова й інших дослідників.

Водночас невирішеною залишається низка питань щодо підстав та умов, порядку огляду на території проведення ООС, гарантій прав учасників слідчої (розшукової) дії, можливостей використання сучасних досягнень техніки для забезпечення безпеки й ефективності проведення огляду, допустимості використання отриманих даних як доказів.

Метою статті $\epsilon$ отримання наукового результату у вигляді теоретичних положень щодо окремих аспектів огляду місця події в районі проведення ООС і формулювання на їх підставі пропозицій щодо вдосконалення чинного законодавства.

Виклад основного матеріалу. Розглянемо особливості процесу огляду місця події під час розслідування кримінальних правопорушень, які вчинилися на території проведення ООС. Огляд місця події $\epsilon$ першочерговою слідчою (розшуковою) дією, яка може бути проведена до внесення відомостей до ЄРДР. Як справедливо зазначає О.В. Лазукова, «...у зв'язку з тимчасовою втратою урядом нашої держави контролю над окремими територіями Донецької і Луганської областей, а також окупацією території АРК у багатьох кримінальних провадженнях узагалі немає реальної можливості проведення огляду місця події. Окрім неможливості проведення цієї слідчої процесуальної дії на вказаних територіях, певні складнощі існують і в разі їі проведення в так званій «сірій зоні», оскільки доступ до неї не завжди $є$ можливим» [2, с. 158]. Складність огляду місця події в зоні ООС не передбачає зменшення вимог до якості огляду й доказів, які отримують у результаті його проведення.

Не потребує доведення наявність великої кількості загроз під час проведення процесуальних дій у «сірій» зоні. Як справедливо зазначають учені, до таких належать загрози здійснення повторних обстрілів, «подвійних» підривів, можливість нападу на слідчо-оперативні групи диверсійно-розвідувальних груп незаконних збройних формувань, можливе мінування території тощо [2, с. 159; 3, с. 114].

Специфіка організації діяльності слідчо-оперативних груп під час розслідування окремих видів злочинів і проведення процесуальних дій на лініях розмежування вимагає додаткового нормативного регулювання цих питань. Так, у 2016 р. було затверджено спільну з ГУНП та УСБУ в Луганській області Інструкцію про порядок внесення відомостей до ЄРДР про вчинення терористичних актів на підконтрольній державній владі України території на лінії розмежування в районі проведення антитерористичної операції, організації діяльності слідчо-оперативних груп та проведення слідчих (розшукових) дій [3, с. 114].

Окрім питань організаційно-тактичного характеру привертають увагу питання нормативного врегулювання проведення огляду місця події в зазначеній категорії кримінальних проваджень. Зокрема С.С. Кудінов привертає увагу до необхідності наділення співробітників оперативних підрозділів правом проводити огляд місця події за дорученням слідчого до внесення відомостей до ЄРДР. Учений обґрунтовує свою позицію тим, що у випадках, коли співробітники оперативних підрозділів у зоні проведення АТО (ООС) виявили місце події (місцевість чи приміщення зі слідами обстрілів, місце вибуху тощо), відповідно до положень ст.ст. 3, 41, 214 КПК України вони не мають права проводити його огляд без доручення слідчого, яке відповідно може бути надано тільки після внесення відомостей до ЄРДР [4, с. 58-59]. Водночас складність і змінюваність обстановки на місці події з причин, які нами були вище зазначені, може призвести до того, що проведення огляду слідчим буде значно відстрочено у часі, а у певних випадках унеможливлено. Все це може вплинути на збереження слідової інформації, можливість вилучення доказів з місця події.

На нашу думку, потребує зміни нормативного врегулювання й питання, що стосується участі судових медиків або лікарів в огляді місця події, на якому наявний труп, а також під час огляду трупа. Відповідно до ч. 3 ст. 214 КПК України єдиною слідчою (розшуковою) дією, яка може бути проведена до внесення відомостей до ЄРДР $\epsilon$ огляд місця події. Таким чином, до внесення відомостей до ЄРДР в разі виявлення на місці події трупа його огляд можливий лише у межах проведення огляду місця події, до якого в обов'язковому порядку залучається судово-медичний експерт або лікар (ч.ч. 1, 2 ст. 238 КПК України). Спільним наказом МВС, МО3, ГП від 29 вересня 2017 р. № 807/1193/279 затверджений Порядок взаємодії між органами й підрозділами Національної поліції, закладами охорони здоров'я та органами прокуратури України під час встановлення факту смерті людини, яким установлено обов'язкову участь в огляді трупа судово-медичного експерта або лікаря в разі виявлення ознак насильницької смерті або підозри на таку (розділ 3 п. 1) [5]. Відповідно до 
п. 1.6 та п. 2.15 Інструкції про проведення судово-медичної експертизи, затвердженої наказом МОЗ від 17 січня 1995 р. № 6, «як фахівці судово-медичні експерти можуть залучатися в установленому законом порядку до участі в початкових та інших слідчих діях: огляду трупів на місці події (знайдення), ексгумації, вилучення зразків та інших» [6].

Фахівці логічно звертають увагу на формулювання цієї норми (ідеться про огляд трупа безпосередньо на місці події), водночас у зазначеній Інструкції відсутні норми, які б визначали можливість і порядок проведення первинного огляду трупів в іншому місці [7, с. 118].

Як нами вже підкреслювалося, огляд місця події в зонах ведення бойових дій пов'язаний з високим ступенем ризику для життя й здоров'я осіб, які перебувають на цих територіях. Практики вказують, що в разі потреби огляду місця події на лінії розмежування працівники поліції узгоджують можливість проведення слідчої (розшукової) дії з командуванням відповідних військових підрозділів i, якщо останні гарантують безпеку слідчо-оперативній групі, необхідні слідчі дії здійснюються безпосередньо на місці виявлення трупа. У випадках, коли така безпека не може бути гарантована, військові, волонтери, які перебувають на місці події, самі доставляють труп у найближче безпечне місце, де проводиться огляд [8, с. 148-149].

На нашу думку, одним зі шляхів розв'язання вищеозначеної проблеми $є$ внесення змін до ч. 3 ст. 214 КПК України, у якій доцільно передбачити можливість огляду трупа як окремої слідчої (розшукової) дії до внесення відомостей до ЄРДР у разі здійснення такого огляду у випадках, коли на місці події існує реальна загроза життю та/або здоров'ю осіб, які беруть участь у цьому огляді. Слід взяти до уваги також пропозиції М.О. Яковенка щодо необхідності доповнення ст. 238 КПК України пунктом 5-м такого змісту: «Огляд трупа може проводитися в іншому місці, якщо на місці його виявлення $\epsilon$ пряма загроза життю або здоров'ю осіб, які беруть участь у цьому огляді» [7, с. 120].

На теперішній час рішення про можливість проведення слідчих (розшукових) дій на лінії розмежування приймають, керуючись здоровим глуздом, але законодавчо це питання прямо не врегульоване. Слід звернути увагу на пропозицію О.В. Лазукової, яка звертається до КПК Казахстану, де в ч. 6 ст. 14 зазначено, що ніхто не може бути залучений до участі в процесуальних діях, якщо останні створюють небезпеку для життя чи здоров'я особи [2, с. 159]. Вважаємо, що доцільно було б доповнити такою нормою і ст. 223 КПК України, якою встановлені вимоги до проведення слідчих (розшукових) дій.

Як логічно зазначає у дисертаційному дослідженні А.Б. Сергеєв, у випадках дії слідчої групи в умовах надзвичайних обставин можна звертатися до «усіченої» тактики огляду місця події, за якої відмовляються від пошуку й описання в протоколі таких деталей місця події, які $\epsilon$ несуттєвими для доказування вчинення певного виду злочину [9, с. 340]. Водночас попередня кваліфікація кримінальних правопорушень у ході кримінального провадження може змінюватися, слідчі не завжди правильно можуть зорієнтуватись у значенні окремих деталей під час огляду, які можуть в подальшому мати велике значення в процесі доказування. Підвищити ефективність дій можна шляхом застосування сучасної криміналістичної техніки. у багатьох країнах світу свою ефективність довела практика застосування лазерних 3D-сканерів під час огляду місця події. Завдяки лазерному 3D-скануванню охоплюються мільйони точок певного реального середовища, завдяки чому створюється його реальна модель, яка містить повне, детальне й об'єктивне відображення слідової картини й обстановки злочину високої точності. Таке фіксування відбувається відносно швидко, а створення завдяки програмному забезпеченню 3D-моделі місця події дає змогу детально його вивчати на будьякому етапі кримінального провадження, використовувати отримані дані для проведення експертиз (адже розміри, розташування об'єктів, так звані «прив'язки» вимірюються з найменшою похибкою, що виключає «людський» фактор) та інших слідчих (розшукових) дій [10, с. 313-314; 11, с. 303]. Серед інших прерогатив лазерних 3D-сканерів О.В. Сараєв у своєму дослідженні застосування цієї технології під час огляду місця дтП виділяє й інші, які, на наше міркування, можуть бути віднесені й до тих випадків, які ми розглядаємо, а саме: підвищення інформативності зібраних даних на місці події, наочна й зручна тривимірна візуалізація, що дає змогу досягти високої ілюстративної якості, подібної до фото- й відеозображення, більш точні вимірювання відстаней і об'єктів за координатами сканованих точок, скорочення в рази часу проведення огляду, можливість проводити слідчі дії в темний час доби, що не впливає на якість сканування та інші. [12, с. 410].

Використання 3D-сканерів під час огляду місця події, особливо в уже описаних нами умовах проведення слідчої (розшукової) дії на лінії розмежування, на нашу думку, об' єктивно могло б оптимізувати роботу слідчо-оперативних груп. Учені, що досліджували зазначене питання, звертають увагу на перепони до застосування такої криміналістичної техніки: фінансування, відсутність в Україні розробленої методики використання й підготованих спеціалістів, чітких процесуальних підстав й умов використання технології 3D-сканерів у доказуванні [10, с. 314].

Крім того, у ч. 7 ст. 237 КПК України зазначається, що під час огляду «слідчий, прокурор або за їх дорученням залучений спеціаліст має право проводити вимірювання, фотографування, звуко- чи відеозапис, складати плани й схеми, виготовляти графічні зображення оглянутого місця чи окремих речей...» Водночас 3D-сканери не просто криміналістична техніка, яка може бути використана під час проведення огляду, це спосіб проведення та фіксації цієї слідчої (розшукової) дії, а отримана 3D-модель логічно $€$ додатком до протоколу огляду. Такий різновид інформації, який може бути визначений як додаток до протоколу, у ч. 2 ст. 105 КПК України відсутній. Тому, як справедливо зазначає О.М. Дуфенюк, доцільно внести зміни до ч. 7 ст. 237 КПК України, включивши 3D-сканери до способів фіксації огляду [10, с. 315].

Висновки. Отже, огляд місця події в районі проведення ООС може характеризуватися швидкою зміною обстановки на місці кримінального правопорушення, пов'язаною з наявністю факторів, що створюють небезпеку для життя й здоров'я учасників слідчої (розшукової) дії. 3 метою забезпечення оперативності, ефективності проведення огляду в зазначених умовах доцільним $\epsilon$ внесення змін до чинного кримінального процесуального законодавства України, а саме: а) розширення 
повноважень співробітників оперативних підрозділів в зоні ООС (надання їм права проводити огляд місця події до внесення відомостей до ЄРДР і без доручення слідчого, прокурора у невідкладних випадках); б) приведення у відповідність нормативно-правових актів, які регулюють питання залучення судового медика до проведення огляду трупа, а також визначення можливості проведення огляду трупа як окремої процесуальної дії до внесення відомостей до ЄРДР; в) створення передумов для впровадження процедури 3D-сканування під час огляду місця події.

Перспективними вбачаються подальші розвідки щодо особливостей нормативного врегулювання й організаційно-тактичних особливостей проведення інших слідчих (розшукових) дій у кримінальних провадженнях, що здійснюються в надзвичайних правових режимах.

\section{Література}

1. Про забезпечення прав і свобод громадян та правовий режим на тимчасово окупованій території України : Закон України від 15 квітня 2014 р. № 1207-VII. Офіційний вісник України. 2014. № 36. Ст. 957.

2. Лазукова О.В. Особливий режим досудового розслідування в умовах воєнного, надзвичайного стану або в районі проведення антитерористичної операції : дис. ... канд. юрид. наук : 12.00.09. Національний юридичний університет імені Ярослава Мудрого. Харків, 2018. 276 с.

3. Цюприк І.В. Особливості збирання доказів у кримінальних провадженнях щодо кримінальних правопорушень, учинених в районі проведення антитерористичної операції. Особливості процесуального доказування в кримінальних провадженнях про злочини, вчинені на тимчасово окупованих територіях : матеріали II круглого столу, м. Сєвєродонецьк, 3 листопада 2017 р. Київ : Національна академія прокуратури України, 2018. С. 114-117.

4. Кудінов С.С. Проблеми правового регулювання порядку збирання доказів під час досудового розслідування, що здійснюється в районі проведення АТО. Особливості процесуального доказування в кримінальних провадженнях про злочини, вчинені на тимчасово окупованих територіях : матеріали II круглого столу, м. Сєвєродонецьк, 3 листопада 2017 р. Київ : Національна академія прокуратури України, 2018. С. 57-59.

\section{Організаційно-правові аспекти досудового слідства}

5. Про затвердження Порядку взаємодії між органами та підрозділами Національної поліції, закладами охорони здоров'я та органами прокуратури України при встановленні факту смерті людини, яким встановлена обов'язкова участь в огляді трупа судово-медичного експерта або лікаря в разі виявлення ознак насильницької смерті або підозри на таку : наказ MBC, MO3, ГП від 29 вересня 2017 p. № 807/1193/279. URL: https://zakon.rada.gov.ua/ laws/show/z1299-17 (дата звернення: 10.11.2019).

6. Інструкція про проведення судово-медичної експертизи : наказ МОЗ України від 17 січня 1995 р. № 6. URL: https://zakon.rada.gov.ua/laws/card/z0254-95.

7. Яковенко М.О. Нормативно-правове забезпечення участі судово-медичного експерта та лікаря під час первинного огляду трупа в зоні проведення бойових дій. Особливості процесуального доказування у кримінальних провадженнях про злочини, вчинені на тимчасово окупованих територіях : матеріали II круглого столу, м. Сєвєродонецьк, 3 листопада 2017 р. Київ : Національна академія прокуратури України, 2018. С. 117-120.

8. Цуцкірідзе М.С. Проблемні питання досудового розслідування в зоні проведення АТО. Особливості процесуального доказування в кримінальних провадженнях про злочини, вчинені на тимчасово окупованих територіях : матеріали II круглого столу, м. Сєвєродонецьк, 3 листопада 2017 р. Київ : Національна академія прокуратури України, 2018. С. 146-150.

9. Сергеев А.Б. Процессуальные проблемы досудебного производства по уголовным делам в чрезвычайных ситуациях : дис. ... д-ра юрид. наук : 12.00 .09 ; Челяб. юрид. ин-т МВД России. Челябинск, 2003. 363 с.

10. Дуфенюк О.М., Марко О.І. Інноваційні технології 3D-сканування в криміналістичній діяльності. Порівняльно-аналітичне право. 2018. № 1. С. 313-315.

11. Дуфенюк О.М., Ковальська М.Ю. Новітні технології у практиці досудового розслідування на прикладі використання 3D-сканерів та смартфонів під час огляду місця події. Порівняльно-аналітичне право. 2018. № 2. С. 303-305.

12. Сараев О.В. Новітні технології дослідження обставин дорожньо-транспортної пригоди. Вісник Національного транспортного університету. 2013. № 28. С. 405-414.

Тетерятник Г. К., кандидат юридичних наук, завідувач кафедри кримінального процесу Одеського державного університету внутрішніх справ 